Original Article

\title{
Genotoxic and cytotoxic evaluation of venlafaxine in an acute and a subchronic assay in mouse
}

\author{
Avaliação genotóxica e citotóxica da venlafaxina em ensaio agudo e subcrônico em \\ camundongos
}

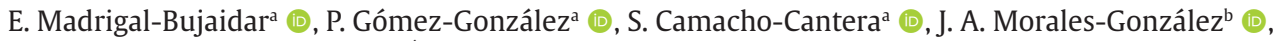 \\ E. Madrigal-Santillán ${ }^{\mathrm{b}}$ (1) and I. Álvarez-González ${ }^{\mathrm{a} *}$ (D) \\ aLaboratorio de Genética, Escuela Nacional de Ciencias Biológicas, Instituto Politécnico Nacional, Zacatenco, Ciudad de México, México \\ bInstituto Politécnico Nacional, Escuela Superior de Medicina, Laboratorio de Medicina de la Conservación, Casco de Santo Tomás, Ciudad de \\ México, México
}

\begin{abstract}
The present research was made to determine the micronuclei and cytotoxic capacity of the antidepressant venlafaxine in an in vivo acute and subchronic assays in mouse. In the first study, we administered once 5, 50, and $250 \mathrm{mg} / \mathrm{kg}$ of the drug, and included a negative and a daunorubicin treated group. Observations were daily made during four days. The subchronic assay lasted 5 weeks with daily administration of venlafaxine $(1,5$, and $10 \mathrm{mg} / \mathrm{kg}) \mathrm{plus}$ a negative and an imipramine administered groups. Observations were made each week. In the first assay results showed no micronucleated polychromatic erythrocytes (MNPE) increase, except with the high dose at $72 \mathrm{~h}$. The strongest cytotoxic effect was found with $250 \mathrm{mg} / \mathrm{kg}$ at $72 \mathrm{~h}$ (a 51\% cytotoxic effect in comparison with the mean control level). In the subchronic assay no MNPE increase was found; however, with the highest dose a significant increase of micronucleated normochromatic erythrocytes was observed in the last three weeks (a mean of 51\% respect to the mean control value). A cytotoxic effect with the two high doses in the last two weeks was observed (a polychromatic erythrocyte mean decrease of $52 \%$ respect to the mean control value). Results suggest caution with venlafaxine.
\end{abstract}

Keywords: antidepressant, micronuclei, cytotoxicity, in vivo assay.

\begin{abstract}
Resumo
A presente pesquisa foi feita para determinar a capacidade micronuclei e citotóxica do antidepressivo venlafaxina em ensaios agudos e subcrônicos in vivo em camundongos. No primeiro estudo, administramos uma vez 5 , 50 e $250 \mathrm{mg} / \mathrm{kg}$ do medicamento e incluímos um grupo negativo e um grupo tratado com daunorubicina. As observações foram feitas diariamente durante quatro dias. O ensaio subcrônico durou cinco semanas com administração diária de venlafaxina $(1,5$, e $10 \mathrm{mg} / \mathrm{kg}$ ) mais um grupo negativo e um grupo administrado de imipramina. As observações foram feitas a cada semana. No primeiro ensaio, os resultados não mostraram aumento de eritrócitos policromáticos micronucleados (MNPE), exceto com a dose elevada a 72 h. O efeito citotóxico mais forte foi encontrado com $250 \mathrm{mg} / \mathrm{kg}$ a 72 h (um efeito citotóxico de $51 \%$ em comparação com o nível médio de controle). No ensaio subcrônico não foi encontrado aumento de MNPE; entretanto, com a dose mais alta, um aumento significativo de eritrócitos normocromáticos micronucleados foi observado nas últimas três semanas (média de $51 \%$ em relação ao valor médio de controle). Foi observado um efeito citotóxico com as duas altas doses nas últimas duas semanas (uma diminuição média de 52\% em relação ao valor médio de controle dos eritrócitos policromáticos). Os resultados sugerem cautela com a venlafaxina.
\end{abstract}

Palavras-chave: antidepressivo, micronuclei, citotoxicidade, ensaio in vivo.

\section{Introduction}

Depression is a serious health and social problem worldwide as shown by its high prevalence, early age of onset, and high persistence in most countries, moreover, it is one of the most common causes of loss of disability-adjusted life-years (Rehm and Shield, 2019). At the global level, over 300 million people are estimated to suffer from depression, equivalent to $4.4 \%$ of the world's population. In México, the total cases with depressive disorders are 4936614 (4.2\% of the population) (WHO, 2017). Therefore, the identification, pharmacological testing and clinical use of antidepressants are always in progress. Venlafaxine is a serotonin-norepinephrine reuptake

*e-mail: isela.alvarez@gmail.com

Received: April 19, 2021 - Accepted: September 24, 2021

This is an Open Access article distributed under the terms of the Creative Commons Attribution License, which permits unrestricted use, distribution, and reproduction in any medium, provided the original work is properly cited. 
inhibitor categorized by IUPAC as 1-[2-dimethylamine-1(4-methoxyphenil) ethyl] ciclohexan-1-ol. It is a racemic mixture of $\mathrm{S}$ and $\mathrm{R}$ enantiomers, where the first enantiomer has been shown to have the greater serotonin reuptake inhibition property, whereas the (R) enantiomer inhibits the reuptake of both monoamines (Godoy et al., 2016).

The drug has become one of the most frequently prescribed medication to treat major depression, with results that have shown to effectively reduce the symptoms of the disease. However, the medicament is also used to treat other health problems such as different forms of anxiety, post-traumatic stress disorder, panic and obsessive-compulsive disorders, as well as attention deficit hyperactivity disorder (Singh and Saadabadi, 2020). According to various authors, venlafaxine should be recommended for use in primary care as a second-line option following the treatment with selective serotonin reuptake inhibitors (Thase et al., 2017; Schueler et al., 2011). Similar to other antidepressants, venlafaxine has manifested a number of moderate collateral symptoms such as fatigue, nausea, somnolence, or mild gastrointestinal problems; however, eventually, the drug can lead to more serious problems, which include severe lactic acidosis, interstitial pneumonitis, neuropathy, different forms of adult and prenatal cardiomyopathy, as well as liver and kidney affections (Paulis et al, 2018; Ko et al., 2018).

With respect to the drug's genotoxic potential a summary of results was published by the U.S. Food and Drug Administration (FDA, 2006). The report indicated that the antidepressant was not mutagenic in various tests: Ames reverse mutation assay in Salmonella, Chinese hamster ovary/HGPRT mammalian cell forward gene mutation assay, in vitro BALB/c-3T3 mouse cell transformation assay, and in the evaluation of sister chromatid exchanges in cultured Chinese hamster ovary cells, as well as in the in vivo chromosomal aberration assay in rat bone marrow. Nevertheless, an increase in DNA damage has been recently found with the comet assay in the brain and liver of mice at 2, 6 and $12 \mathrm{~h}$ post-administration with 50 and $250 \mathrm{mg} /$ kg (Gómez-González, 2017). Other reports have also found abnormal effects by the drug, for example, alterations in the rat prenatal development during pregnancy (Da Silva et al., 1999), or birth defects related with periconceptional use of the antidepressant (Polen et al., 2013). Moreover, ecological damage related with venlafaxine aquatic contamination has also been reported, as shown by alterations in the immune system of the blue mussel (Lacaze et al., 2015), boost of locomotion as a prelude to foot detachment in the oyster drill (Urosalpinx cinerea) and the star snail (Lithopoma americanum) (Fong et al., 2015), decrease in the brain serotonin level and in predation behavior in the striped bass (Bisesi et al., 2014), and disruption of brain monoamine levels and neuroendocrine responses in rainbow trout (Melnyk-Lamont et al., 2014). Also, in a transgenerational study in Daphnia magna (Minguez et al., 2015), authors found that venlafaxine exposure decreased the offspring number of F0 daphnids and caused drug tolerance in the F1 generation. Moreover, in another report (Singh et al., 2015), rat neocortices exposed to venlafaxine were found to significantly increase the level of reactive oxygen species. In this context, the report by
Ayabakti and Kokaman (2020) is of relevance because the authors demonstrated that venlafaxine is an inducer of chromosome aberrations and micronuclei in cultivated human lymphocytes.

In light of the preceding information, which also includes the absence of in vivo micronuclei examination for venlafaxine exposure, we considered pertinent to carry out two experiments to determine whether the antidepressant was able to induce such chromosomal damage in mouse, as well as to define its cytotoxic potential also in mouse. The first assay was of acute type and lasted four days, while the second assay had a duration of five weeks.

\section{Materials and Methods}

\subsection{Chemical and animals}

Venlafaxine (Effexor XR® Pfizer Inc., Mexico City) was obtained as the usually prescribed pharmaceutical medication. Daunorubicin and imipramine were purchased from Sigma Chemicals (St Louis MO, USA). The Giemsa stain was obtained from Merck (Mexico City), and methanol, potassium phosphate, and sodium phosphate, the salts to prepare buffers, were obtained from J.T. Baker S.A. (Mexico City).

For the two assays of the present report we used CD1 male mice obtained from the bioterium of the Autonomous University of the state of Hidalgo, México. The animals were conditioned for a week in the Animal House of the Genetics Laboratory before starting the assays. They were kept in polypropylene cages at $23 \pm 1{ }^{\circ} \mathrm{C}, 50-60 \%$ relative humidity, and on a 12/12 h dark-light cycle (lights on at 7 AM). Mice were freely fed with rodent food (Rodent laboratory Chow 5001, Purina, St. Louis MO, U.S.A.), and purified water. The experimental assays were approved by the Ethics Committee of the Autonomous University of Hidalgo state, Mexico, and follow the international recommendations of ARRIVE guidelines, published in Arrive (2020).

\subsection{Acute genotoxic assay}

The present experimental design was based on previous reports on the matter (Madrigal-Bujaidar et al., 2015, 2020; Cristobal-Luna et al., 2018). Thirty mice with a mean weight of $28 \mathrm{~g}$ were used for the experiment. Animals were distributed in five groups with 6 individuals each. One group corresponded to control animals and were intragastrically (ig) administered with $10 \mathrm{~mL} / \mathrm{kg}$ of purified water; another three groups were designed to test the ability of venlafaxine to induce micronuclei and were ig administered with the drug in doses of 5,50 , and $250 \mathrm{mg} / \mathrm{kg}$; finally, we included a positive control group intraperitoneally (ip) treated with $2.5 \mathrm{mg} / \mathrm{kg}$ of daunorubicin. In the study, the low tested dose of venlafaxine corresponded to the recommended high therapeutic dose in humans ( $375 \mathrm{mg} /$ day); moreover, daunorubicin was selected as positive agent because it is a well-known antineoplastic agent that causes DNA damage in various genotoxic tests, including the micronucleus assay (Madrigal-Bujaidar et al., 2015; Cristobal-Luna et al., 2018). 
Before the administration of the mentioned substances, a peripheral blood sample from the tail of each mouse was taken and extended on two clean slides, then, cells were fixed in absolute methanol for $5 \mathrm{~min}$, washed in running water, dried, and stained with $5 \%$ Giemsa solution made in PBS ( $\mathrm{pH}$ of 6.8 ) for $12 \mathrm{~min}$. All animals were then placed in their corresponding cages for the next four days. During such period, with a procedure similar to the one described earlier, the peripheral blood examination was carried out at $24,48,72$, and 96 h post-treatment.

Microscopic observation to determine the genotoxic potential of venlafaxine included the quantification of micronucleated polychromatic erythrocytes (MNPE) in 3.000 polychromatic erythrocytes (PE) per mouse. Besides, to examine the bone marrow cytotoxic potential of venlafaxine we determined the proportion of PE with respect to the number of normochromic erythrocytes (NE) in 3.000 erythrocytes per mouse.With our staining procedure it was easy to clearly differentiate between PE and NE. The first mentioned cell shows a blue color, mainly due to its RNA content, and is somewhat larger than NE. This last cell is stained in pinkish and is the most abundant in the frotis (Gollapudi and Kamra, 1979).

Statistical significance of the obtained results was carried out by means of an Kruskal-Wallis test followed by a post hoc Tukey test using the Sigma Plot software, version 12.1

\subsection{Subchronic genotoxic assay}

The study was based in previous reports (MadrigalBujaidar et al., 2008, 2015) and was developed in the same experimental conditions as previously described for the acute assay. However, in the present experiment all groups were administered daily with the used chemicals by the ig route for five weeks. Experimental groups were organized as follows: a control group which was administered with $10 \mathrm{~mL} / \mathrm{kg}$ of purified water, three groups administered venlafaxine in the doses of 1,5 , and $10 \mathrm{mg} / \mathrm{kg}$, and a positive control group treated with $10 \mathrm{mg} / \mathrm{kg}$ of imipramine. In the study, the low dose of the antidepressant corresponded to the low therapeutic dose used in humans $(75 \mathrm{mg}$ / day), and the use of imipramine was decided because of results observed in a preliminary assay with the indicated dose, and on account of previous positive effect obtained with such drug regarding the induction of micronuclei (Madrigal-Bujaidar et al., 2008).

Blood smears from the tail of each animal were obtained before the administration of chemicals, as well as at the end of each week during the whole experiment. Cells were treated with a procedure similar to the one described for the acute assay in respect to fixation, washing, and staining.

In the present assay, the weight of the animals was registered every third day along the established schedule. Besides, microscopic observations per mouse were as follows: 1- to determine the genotoxic potential of the drug in young cells, we registered the number of MNPE in 3.000 PE, 2- to examine the genotoxic potential in mature cells we registered the incidence of micronuclei in normochromic erythrocytes (MNNE) in 3.000 erythrocytes, and 3- to evaluate the effect of venlafaxine in bone marrow proliferation we determined the proportion of PE with respect to normochromic erythrocytes (NE) in 3.000 erythrocytes.

The obtained data were expressed in percent. Statistical evaluation of the results was determined by means of a Kruskal-Wallis test followed by a post hoc Tukey test using a Sigma Plot software, version 12.1.

\section{Results}

Figure 1 shows the percent of MNPE determined in the acute and the subchronic assays. In the first case (Figure 1A), it was observed that the untreated, control animals, showed a micronuclei mean number of $0.12 \%$ along the studied schedule, a contrasting result with respect to the effect induced by daunorubicin, which gave rise to an elevated number of MNPE, mainly at 48 and $72 \mathrm{~h}$. The highest increase with this agent was found at $48 \mathrm{~h}$ post-administration with a mean value of $1.78 \%$. In relation to the micronuclei induction by the evaluated antidepressant no effect was detected from 24 to $48 \mathrm{~h}$, and we found that only the high tested dose gave rise to certain genotoxic effect at $72 \mathrm{~h}$.

With respect to the subchronic assay (Figure 1B) the registered MNPE number in the control group showed between 0.1 and $0.3 \%$ lesions along the study; also, venlafaxine administration clearly maintained a similarly low level along the five weeks of the assay; while a significant elevation of micronuclei was produced by imipramine during the last three weeks of the study.

Figure 2 shows the results obtained in relation to the induction of MNNE in the subchronic assay. In this case, the level of micronuclei in the control group was found between 0.4 and $0.6 \%$ lesions along the study; venlafaxine showed certain micronuclei increase in week 1 ; however, a significant elevation of genotoxicity induced by the drug was observed during the last three weeks of the treatment. In week 4 and 5 the MNNE increase with the dose of 10 $\mathrm{mg} / \mathrm{kg}$ of venlafaxine was 51 and $58 \%$ with respect to the control level.

The mouse weight gain in the subchronic assay is presented in Table 1 . We observed a normal weight increase in the control group along the five-week study (7,35 g); however, mice treated with imipramine showed almost no weight elevation, suggesting certain systemic toxicity, and in the case of animals administered venlafaxine the weight increase was moderate going from 2 to $5 \mathrm{~g}$.

As regards the cytotoxic effect of venlafaxine, results of the acute and the subchronic assays are shown in Figure 3. In the acute study (Figure $3 \mathrm{~A}$ ) one observes a consistently uniform value of the erythrocyte proportion in the control group, with a mean percent of $4.1 \mathrm{PE}$ with respect to the total number of erythrocytes, a result that contrasts with the significant decrease in the number of PE along the $96 \mathrm{~h}$ of the study in the daunorubicin treated group, with the highest decrease at $72 \mathrm{~h}$ of administration, that corresponds to $60 \%$ reduction in relation to the control level at that time. These data agree with the reported cytotoxic capacity of the agent. As to the results obtained with venlafaxine, interestingly, no effect was observed with 


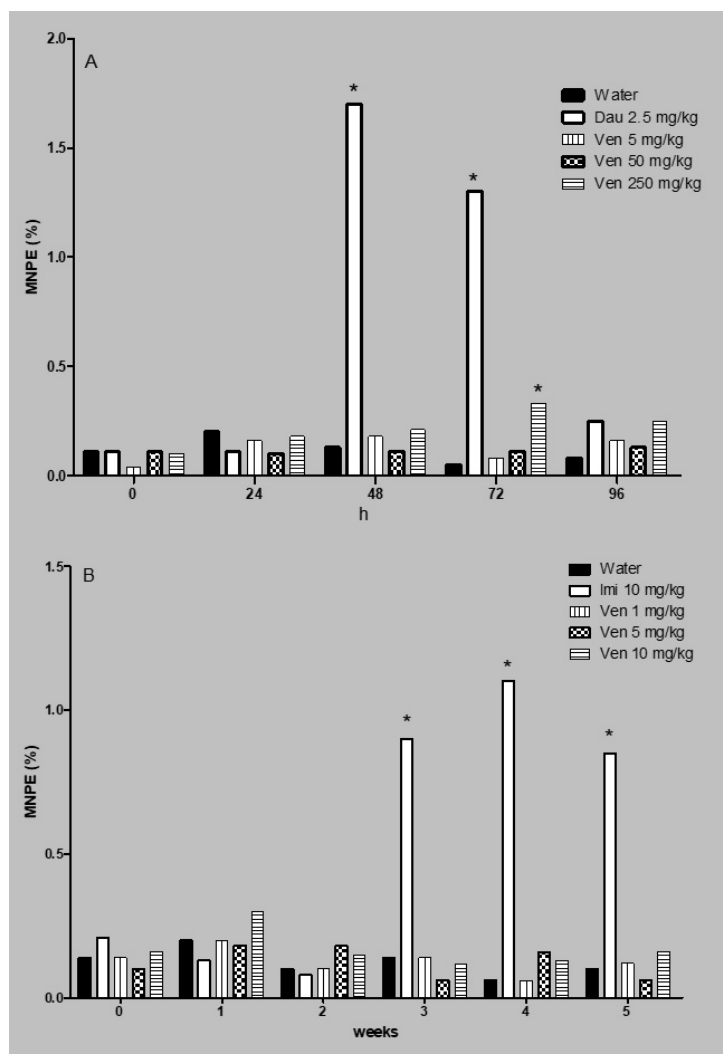

Figure 1. Effect of venlafaxine (Ven) on the induction of micronucleated polychromatic erythrocytes in mouse. $\mathrm{A}=$ acute assay, $\mathrm{B}=$ subchronic assay. Dau = daunorrubicin, $\mathrm{Imi}=$ imipramine. Each bar represents the MNPE mean percentage obtained in 3000 polychromatic erythrocytes per mouse. Six animals per group. ${ }^{*}$ Statistical difference with respect to control value. Kruskal-Wallis followed by post hoc Tukey test, $\mathrm{p} \leq 0.05$.

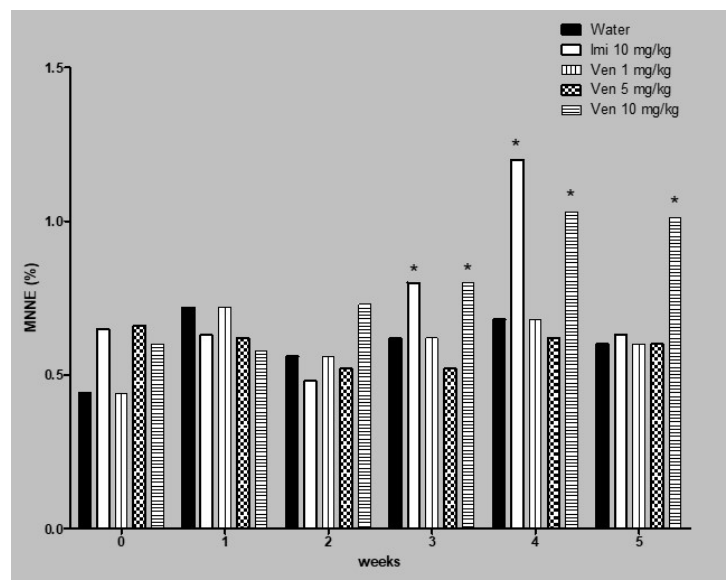

Figure 2. Effect of venlafaxine (Ven) on the induction of MNNE in mouse. Subchronic assay. Imi= imipramine. Each bar represents the mean percentage obtained in 3000 cells per mouse. Six animals per group. *Statistical difference with respect to control value. Kruskal-Wallis followed by post hoc Tukey test, $\mathrm{p} \leq 0.05$.

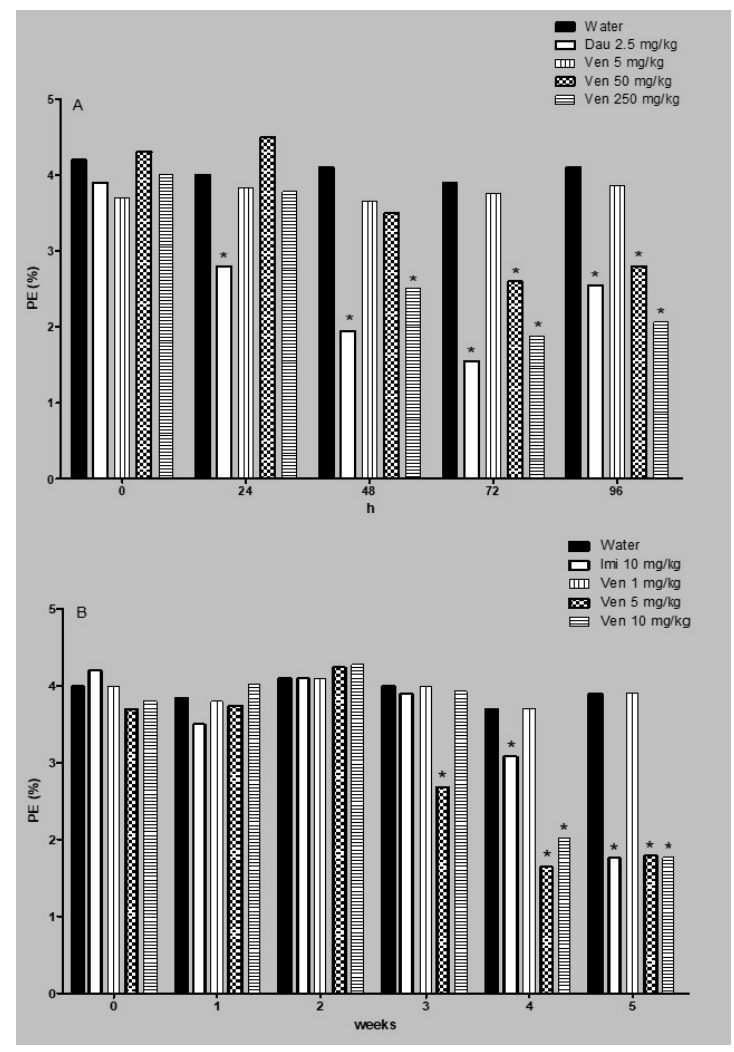

Figure 3. Cytotoxic evaluation of venlafaxine. Number of polychromatic erythrocyte respect to the total number of erythrocytes. $\mathrm{A}=$ acute assay. $\mathrm{B}=$ subchronic assay. Dau = daunorrubicin. Imi= imipramine. Each bar represents the mean percentage obtained in 3000 cells per mouse. Six animals per group. ${ }^{*}$ Statistical difference with respect to control value. Kruskal-Wallis followed by post hoc Tukey test, $\mathrm{p} \leq 0.05$.

the low dose, but a significant inhibition of bone marrow cell proliferation was noted with the two high doses from 48 to $96 \mathrm{~h}$ of exposure, being the strongest cytotoxic effect induced with $250 \mathrm{mg} / \mathrm{kg}$ of the drug at $72 \mathrm{~h}$ (a reduction of $51 \%$ respect to the control level).

The set of results shown in Figure 3B corresponds to the effect of the antidepressant on the bone marrow proliferation during the five-week assay. In this determination, a significant decrease of the PE count was detected with the two high doses ( 5 , and $10 \mathrm{mg} / \mathrm{kg}$ ) in the two last weeks of the assay.

\section{Discussion}

The micronucleus test is one of the most used genotoxicity tests because of a number of advantages. These include the fact that micronuclei can be obtained in most dividing cells, independently of the organism's karyotype, besides, other advantage is the relative easiness to their identification, and therefore, it can provide accurate data; moreover, that background frequencies of micronucleated 
Table 1. Weight of mice administered with venlafaxine during the 5 week-assay.Each data shows the mean \pm SDM of six mice per group.

\begin{tabular}{|c|c|c|c|c|c|}
\hline Week & Water & $\begin{array}{l}\text { Imipramine } \\
10 \mathrm{mg} / \mathrm{kg}\end{array}$ & $\begin{array}{c}\text { Venlafaxine } \\
1 \mathrm{mg} / \mathrm{kg}\end{array}$ & $\begin{array}{c}\text { Venlafaxine } \\
5 \mathrm{mg} / \mathrm{kg}\end{array}$ & $\begin{array}{c}\text { Venlafaxine } \\
10 \mathrm{mg} / \mathrm{kg}\end{array}$ \\
\hline 0 & $24.40 \pm 0.56$ & $30.51 \pm 4.70$ & $27.50 \pm 2.83$ & $27.22 \pm 2.25$ & $28.26 \pm 3.93$ \\
\hline 1 & $26.00 \pm 1.83$ & $29.96 \pm 5.50$ & $28.64 \pm 5.39$ & $27.96 \pm 2.74$ & $29.40 \pm 3.86$ \\
\hline 2 & $28.70 \pm 0.28$ & $30.81 \pm 4.00$ & $30.22 \pm 6.46$ & $30.44 \pm 3.20$ & $32.46 \pm 3.77$ \\
\hline 3 & $31.10 \pm 2.40^{*}$ & $31.00 \pm 4.62$ & $30.10 \pm 6.22$ & $29.72 \pm 3.29$ & $32.05 \pm 2.9$ \\
\hline 4 & $31.75 \pm 0.21^{*}$ & $32.30 \pm 4.60$ & $31.52 \pm 6.09$ & $30.24 \pm 3.20$ & $33.20 \pm 2.53^{*}$ \\
\hline 5 & $31.75 \pm 0.21^{*}$ & $30.56 \pm 4.72$ & $29.90 \pm 5.99$ & $30.16 \pm 3.15$ & $33.00 \pm 2.94^{*}$ \\
\hline
\end{tabular}

${ }^{*}$ Statistically significant difference with respect to week 0. ANOVA followed by a post hoc Student's t test, $p<0.05$.

cells are usually stable (Hayashi, 2016). Furthermore, the in vivo test is internationally accepted for regulatory agencies as an essential method to evaluate compounds with carcinogenic potential (Sales et al., 2018). The test can be applied in mouse to determine the genotoxic effect in young cells (PE), a procedure that reveals the damage occurred in a recent, short time, but the examination can also be done to mature cells (NE), where it is possible to examine cumulative damage exerted by the tested chemical (Hayashi, 2016; MacGregor et al., 1980). Due to these characteristics, it seemed advisable to determine the effect of venlafaxine with such two designs in order to ratify, rectify or add new information to the previously published genotoxic data on the antidepressant.

Our results in the four-day study examining MNPE revealed almost no micronuclei induction capacity by the antidepressant with the three tested doses, suggesting that the compound can be used safely according to this parameter. We solely observed MNPE increase at $72 \mathrm{~h}$ of venlafaxine exposure. Moreover, such result was congruent with the absence of damage measuring MNPE in the subchronic assay. However, a significant MNNE increase induced with the high tested dose of venlafaxine $(250 \mathrm{mg} /$ $\mathrm{kg}$ ) was observed in the last three weeks of the subchronic study, indicating a cumulative effect. In weeks 4 and 5 , the increase over the respective control value was 51 and $68 \%$. This improved effect can be reached when animals are treated continuously for about 4 weeks (FDA, 2000). These differential data in the two applied tests confirm the importance of evaluating micronuclei (or other genotoxic endpoints) in short and longer times, as well as by using various doses. Even so, in spite of the mentioned positive effect, our present results cannot suggest a significant genotoxic hazard for patients under appropriate venlafaxine treatment, given that the observed effect was found with a higher dose than the one therapeutically prescribed. Moreover, our present result agrees with the obtained in the brain and liver of mouse using the comet assay, which showed DNA damage only with high doses (Gómez-González, 2017). Nevertheless, our results may be a warning to keep the prescribed doses in the present range, as well as to further evaluate the administration of the drug in longer assays. Moreover, in a previous study made in cultivated human lymphocytes the authors found a stronger chromosome and micronuclei damage by venlafaxine than the observed in the acute assay of the present report. As the authors did not use the $S 9$ fraction it can be concluded that the detected effect was exclusively due to the original venlafaxine molecule, without the influence of any metabolite (Ayabakti and Kokaman, 2020). In contrast, in our 96 h assay, the almost absence of damage may be related with the rapid half-life time of the drug (about $5 \mathrm{~h}$ ) that permits the biotransformation and detoxification of the drug, as well as the repair of its effects along the assay. These differences point to the importance to carry out different genotoxic methods and times of observation to reach a final conclusion on the genotoxic potential of venlafaxine, moreover, considering our finding in the subchronic assay related with the accumulation of micronuclei.

Regarding venlafaxine genotoxicity, interestingly, interaction of the drug with DNA has been previously established by means of physico-chemical techniques and molecular simulation studies, research which suggests that the union occurs by a minor groove binding mode (Shahabadi et al., 2015). Besides, by means of the DNA microarray method applied to human lymphocytes of depressive patients treated with venlafaxine, it was detected that 31 genes were more highly expressed and 26 genes were significantly less abundant (Kálmán et al., 2005), also suggesting that the drug exposure may affect the DNA.

In regard to venlafaxine cytotoxicity, our results in the short-term assay showed a decrease in bone marrow proliferation with the two high doses, as revealed by the decreased number of PE from the 48 to 96 h of the study. In this period the mean $\mathrm{PE}$ decrease with respect to the mean value of the control group was $36 \%$. This result agrees with the diminished number of PE in the subchronic assay, particularly in the last two weeks. The decrease caused by the two high doses in the last week was $54 \%$. The observed PE decrease in the acute and the subchronic assays indicates bone marrow cytotoxicity induced by the drug due to a reduction of the erythropoiesis.

The underlying explanation of the described effect (as well as to the genotoxic damage) may be congruent with reports that have determined oxidative potential of the antidepressant. In this field, a study by Plachá et al. (2016), concluded that venlafaxine was not capable of scavenging the superoxide anion radical generated in the $\mathrm{KO}_{2} / \mathrm{DMSO}$ system, which indicates that it is not an 
efficient electron/proton donor molecule. Besides, Singh and Sharma (2016) established that rat prenatal exposure to venlafaxine enhances the generation of reactive oxygen species, a situation which played a key role in regulating the release of pro-apoptotic factors from mitochondria, thereby heightening apoptotic neurodegeneration that affects proliferation, migration and differentiation of cells. Also, our geno/cytotoxic results are also in line with the increase of reactive oxygen species found in rat neocortices exposed to the drug (Sinh et.al., 2015), moreover, other antidepressants, such as duloxetine, have produced oxidative damage to lipids, proteins, and DNA in mouse liver and brain (Alvarez-González et al., 2021). However, the conclusion reached on this matter is presently controversial given that venlafaxine has also been reported to have antioxidant potential. In this last aspect, research has shown that the drug can be beneficial at the brain and medulla levels to depression-induced rats due to the reduction of free radical production (Eren et al., 2007); furthermore, the medication protected from cell injury exerted by methylglyoxal through a reduction of reactive oxygen species and release of the anti-apoptotic Bcl-2 molecule in cultured human brain cells (Lv et al., 2014). Moreover, Khanam et al. (2012) found a decrease of thiobarbituric acid reactive substance and restoration of glutathione levels in diabetes-induced depressive mice, in addition, Abdel-Wahab and Salama (2011) reported that in mice subjected to forced swimming and tail suspension tests, the antidepressant reduced the levels of lipoperoxidation, nitric oxide, gluthatione, and 8-hydroxy-2'-deoxyguanosine in the hypoccampus. The mentioned opposing data clearly point to the relevance of future research concerning venlafaxine oxidative or antioxidative properties, which could probably be connected with specific experimental conditions, including the used dose and exposure route/ time, as well as with the involvement of different molecular or cellular targets. Such knowledge is relevant considering that in vivo bioactivation of compounds may form a carbon, or nitrogen centered primary radicals with unstable, unpaired electrons that react rapidly with a wide variety of cellular macromolecules (Sinha, 2020). Therefore, a further knowledge on the matter may be useful to better understand the antidepressant mechanism of action as well as to design new applications of the drug.

\section{Conclusion}

In the acute assay, our results showed genotoxicity and cytotoxicity only with the highest dose $(250 \mathrm{mg} / \mathrm{kg})$ at $72 \mathrm{~h}$. In regard to the subchronic assay, we observed genotoxic damage with the highest tested dose (10 mg/ $\mathrm{kg}$ ) in the last three weeks, but only in normochromatic erythrocytes, suggesting then cumulative damage induced by the drug; regarding the cytotoxic effect, this was shown with the two high doses, in the last two weeks. Our data suggest the importance of maintaining the therapeutic doses of venlafaxine in the present range, the pertinence to further evaluate the cytotoxic potential of the drug, and the need to examine its geno/cytotoxic potential in long-term treated patients.

\section{References}

ABDEL-WAHAB, B.A. and SALAMA, R.H., 2011. Venlafaxine protects against stress-induced oxidative DNA damage in hippocampus during antidepressant testing in mice. Pharmacology, Biochemistry, and Behavior, vol. 100, no. 1, pp. 59-65. http:// dx.doi.org/10.1016/j.pbb.2011.07.015. PMid:21835191.

ALVAREZ-GONZÁLEZ, I., CAMACHO-CANTERA, S., GÓMEZGONZÁLEZ, P., RENDON-BARRÓN, M.J., MORALES-GONZÁLEZ, J.A., MADRIGAL-SANTILLÁN, E.O., PANIAGUA-PÉREZ, R. and MADRIGAL-BUJAIDAR, E., 2021. Genotoxic and oxidative effect of duloxetine on mouse brain and liver tissues. Scientific Reports, vol. 11, pp. 6897-6907. https://doi org/10.1038/s41598-021-86366-0.

ARRIVE, 2020 [viewed 3 November 2021]. ARRIVE guidelines [online]. Available from: https://arriveguidelines.org

AYABAKTI, S. and KOKAMAN, A. Y., 2020. Cytogenotoxic effects of venlafaxine hydrochloride on cultured human peripheral blood lymphocytes. Drug and Chemical Toxicoly, vol. 43, no. 2, pp. 192-199. https://doi org/10.1080/01480545.2018.1486410.

BISESI, J.R., JOSEPH, H., BRIDGES, W. and KLAINE, S.J., 2014. Effects of the antidepressant venlafaxine on fish brain serotonin and predation behavior. Aquatic Toxicology (Amsterdam, Netherlands), vol. 151, pp. 88-96. http://dx.doi.org/10.1016/j. aquatox.2014.02.015. PMid:24679646.

CRISTOBAL-LUNA, J.M., PANIAGUA-CASTRO, N., ESCALONACARDOSO, G.N., PÉREZ-GUTIÉRREZ, M.S., ÁLVAREZ-GONZÁLEZ, I., MADRIGAL-BUJAIDAR, E. and CHAMORRO-CEVALLOS, G., 2018. Evaluation of teratogenicity and genotoxicity induced by kramecyne (KACY). Saudi Pharmaceutical Journal, vol. 26, no. 6, pp. 829-838. http://dx.doi.org/10.1016/j.jsps.2018.03.016. PMid:30202224.

DA-SILVA, V.A., ALTENBURG, S.P., MALHEIROS, R.L., THOMAZ, T.G. and LINDSEY, C.J., 1999. Postnatal development of rats exposed to fluoxetine or venlafaxine during the third week of pregnancy. Brazilian Journal of Medical and Biological Research, vol. 32, no. 1, pp. 93-98. http://dx.doi.org/10.1590/S0100879X1999000100014. PMid:10347775.

EREN, I., NAZIROĞLU, M., DEMIRDAŞ, A., CELIK, O., UĞUZ, A.C., ALTUNBAŞAK, A., OZMEN, I. and UZ, E., 2007. Venlafaxine modulates depression-induced oxidative stress in brain and medulla of rat. Neurochemical Research, vol. 32, no. 3, pp. 497-505. http://dx.doi.org/10.1007/s11064-006-9258-9. PMid: 17268845.

FONG, P.P., BURY, T.B., DWORKIN-BRODSKY, A.D., JASION, C.M. and KELL, R.C., 2015. The antidepressants venlafaxine ("Effexor") and fluoxetine ("Prozac") produce different effects on locomotion in two species of marine snail, the oyster drill (Urosalpinx cinerea) and the starsnail (Lithopoma americanum). Marine Environmental Research, vol. 103, pp. 89-94. http://dx.doi. org/10.1016/j.marenvres.2014.11.010. PMid:25481651.

GODOY, A.L., ROCHA, A., DA SILVA SOUZA, C. and LANCHOTE, V.L., 2016. Pharmacokinetics of venlafaxine enantiomers and their metabolites in psoriasis patients. Journal of Clinical Pharmacology, vol. 56, no. 5, pp. 567-575. http://dx.doi.org/10.1002/jcph.630. PMid:26331791.

GOLLAPUDI, B. and KAMRA, O.P., 1979. Applications of a simple Giemsa-staining method in the micronucleus test. Mutation Research, vol. 64, no. 1, pp. 45-46. http://dx.doi.org/10.1016/01651161(79)90135-3. PMid:86950.

GÓMEZ-GONZÁLEZ, P., 2017. Evaluación de la capacidad genotóxica y oxidativa de la venlafaxina en ratón. México: Escuela Nacional de Ciencias Biológicas, Instituto Politécnico Nacional, 80 p. Master's Dissertation on Toxicology of venlafaxin. 
HAYASHI, M., 2016. The micronucleus test-most widely used in vivo genotoxicity test-. Genes and Environment : the Official Journal of the Japanese Environmental Mutagen Society, vol. 38, no. 1, pp. 18. http://dx.doi.org/10.1186/s41021-016-0044-x. PMid:27733885.

KÁLMÁN, J., PALOTÁS, A., JUHÁSZ, A., RIMANÓCZY, A., HUGYECZ, M., KOVÁCS, Z., GALSI, G., SZABÓ, Z., PÁKÁSKI, M., FEHÉR, L.Z., JANKA, Z. and PUSKÁS, L.G., 2005. Impact of venlafaxine on gene expression profile in lymphocytes of the elderly with major depression-evolution of antidepressants and the role of the "neuro-immune" system. Neurochemical Research, vol. 30, no. 11, pp. 1429-1438. http://dx.doi.org/10.1007/s11064005-8513-9. PMid:16341940.

KHANAM, R., NAJFI, H., AKHTAR, M. and VOHORA, D., 2012. Evaluation of venlafaxine on glucose homeostasis and oxidative stress in diabetic mice. Human and Experimental Toxicology, vol. 31, no. 12, pp. 1244-1250. http://dx.doi. org/10.1177/0960327112446840. PMid:22751285.

KO, J.U., SEO, H., LEE, G.J. and PARK, D., 2018. Bilateral sciatic neuropathy with severe rhabdomyolysis following venlafaxine overdose: a case report. Medicine, vol. 97, no. 37, pp. e12220. http://dx.doi.org/10.1097/MD.0000000000012220. PMid:30212953.

LACAZE, E., PEDELUCQ J., FORTIER, M., BROUSSEAU, P., AUFFRET, M., BUDZINSKI, H. and FOURNIER, M., 2015. Genotoxic and immunotoxic potential effects of selected psychotropic drugs and antibiotics on blue mussel (Mytilus edulis) hemocytes. Environmental Pollution, vol. 202, pp. 177-186. http://dx.doi. org/10.1016/j.envpol.2015.03.025. PMid:25829077.

LV, Q., GU, C. and CHEN, C., 2014. Venlafaxine protects methylglyoxalinduced apoptosis in the cultured human brain microvascular endothelial cells. Neuroscience Letters, vol. 569, pp. 99-103. http://dx.doi.org/10.1016/j.neulet.2014.03.010. PMid:24631568.

MACGREGOR, J.T., WEHR, C.M. and GOULD, D.H., 1980. Clastogeninduced micronuclei in peripheral blood erythrocytes: the basis of an improved micronucleus test. Environmental Mutagenesis, vol. 2, no. 4, pp.509-514. http://dx.doi.org/10.1002/ em.2860020408. PMid:6796407.

MADRIGAL-BUJAIDAR, E., ÁLVAREZ-GONZÁLEZ, I., MADRIGALSANTILLÁN, E.O. and MORALES-GONZÁLEZ, J.A., 2015. Evaluation of duloxetine as micronuclei inducer in an acute and a subchronic assay in mouse. Biological \& Pharmaceutical Bulletin, vol. 38, no. 8, pp. 1245-1249. http://dx.doi.org/10.1248/bpb.b15-00152. PMid:26235590.

MADRIGAL-BUJAIDAR, E., CERÓN-MONTES, G.I., REYES-MIRANDA, J., VERGARA-HERNÁNDEZ, E., ÁLVAREZ-GONZÁLEZ, I., MORALESRAMÍREZ, A.D.J., FRANCISCO-MARTÍNEZ, L.E. and GARRIDOHERNÁNDEZ, A., 2020. Structural, luminescence and geno/ cytoxicity study of carbon dots derived from Opuntia ficus-indica (L.) Mill. New Journal of Chemistry, vol. 44, no. 3, pp. 942-950. http://dx.doi.org/10.1039/C9NJ03771C.

MADRIGAL-BUJAIDAR, E., MADRIGAL-SANTILLÁN, E.O., ÁLVAREZGONZÁLEZ, I., BAEZ, R. and MÁRQUEZ, P., 2008. Micronuclei induced by imipramine and desipramine in mice: a subchronic study. Basic \& Clinical Pharmacology \& Toxicology, vol. 103, no. 6 , pp.569-573. http://dx.doi.org/10.1111/j.1742-7843.2008.00328.x. PMid: 19067683.

MELNYK-LAMONT, N., BEST, C., GESTO, M. and VIJAYAN, M.M., 2014. The antidepressant venlafaxine disrupts brain monoamine levels and neuroendocrine responses to stress in rainbow trout. Environmental Science E Technology, vol. 48, no. 22, pp. 1343413442. http://dx.doi.org/10.1021/es504331n. PMid:25356744.

MINGUEZ, L., BALLANDONNE, C., RAKOTOMALALA, C., DUBREULE, C., KIENTZ-BOUCHART, V. and HALM-LEMEILLE, M.P., 2015.
Transgenerational effects of two antidepressants (sertraline and venlafaxine) on Daphnia magna life history traits. Environmental Science E Technology, vol. 49, no. 2, pp. 1148-1155. http://dx.doi. org/10.1021/es504808g. PMid:25506746.

PAULIS, M.G., HAFEZ, E.M., EL-TAHAWY, N.F. and ALY, M.K.M., 2018. Toxicological assessment of venlafaxine: acute and subchronic toxicity study in rats. International Journal of Toxicology, vol. 37, no. 4, pp. 327-334. http://dx.doi.org/10.1177/1091581818777470. PMid:29862856.

PLACHÁ, K., VALACHOVÁ, K., RAPTA, P., TOPOL'SKÁ, D., MELICHERCÍKOVÁ, K. and SOLTÉS, L., 2016. Effect of venlafaxine on scavenging free radicals in vitro. Neuroendocrinology Letters, vol. 37, no. 1, pp. 59-64. PMid:26994387.

POLEN, K.N.D., RASMUSSEN, S.A., RIEHLE-COLARUSSO, T. and REEFHUIS, J.2013. Association between reported venlafaxine use in early pregnancy and birth defects, national birth defects prevention study, 1997-2007. Birth Defects Research. Part A, Clinical and Molecular Teratology, vol. 97, no. 1, pp. 28-35. http:// dx.doi.org/10.1002/bdra.23096. PMid:23281074.

REHM, J. and SHIELD, K.D., 2019. Global burden of disease and the impact of mental and addictive disorders. Current Psychiatry Reports, vol. 21, no. 2, pp. 10. http://dx.doi.org/10.1007/s11920019-0997-0. PMid:30729322.

SALES, I.M.S., SILVA, J.M., MOURA, E.S.R., ALVES, F.D.S., SILVA, F.C.C., SOUSA, J.M.C. and PERON, A.P., 2018. Toxicity of synthetic flavorings, nature identical and artificial, to hematopoietic tissue cells of rodents. Brazilian Journal of Biology $=$ Revista Brasileira de Biologia, vol. 78, no. 2, pp. 306-310. http://dx.doi. org/10.1590/1519-6984.07716. PMid:28832835.

SCHUELER, Y.B., KOESTERS, M., WIESELER, B., GROUVEN, U., KROMP, M., KEREKES, M.F., KREIS, J., KAISER, T., BECKER, T. and WEINMANN, S., 2011. A systematic review of duloxetine and venlafaxine in major depression, including unpublished data. Acta Psychiatrica Scandinavica, vol. 123, no. 4, pp. 247-265. https://doi.org/10.1111/j.1600-0447.2010.01599.x.

SHAHABADI, N., HADIDI, S., GHASEMIAN, Z. and TAHERPOUR, A.A., 2015. Racemic R, S-venlafaxine hydrochloride-DNA interaction: experimental and computational evidence. Spectrochimica Acta. Part A, Molecular and Biomolecular Spectroscopy, vol. 145, pp. 540-552. http://dx.doi.org/10.1016/j.saa.2015.03.073. PMid:25801443.

SINGH, D. and SAADABADI, A., 2020 [viewed 3 November 2021]. Venlafaxine [online]. Treasure Island (FL): StatPearls Publishing. Available from: https://www.ncbi.nlm.nih.gov/ books/NBK535363/

SINGH, P. and SHARMA, B., 2016. Selective serotonin-norepinephrine re-uptake inhibition limits renovascular-hypertension induced cognitive impairment, endothelial dysfunction, and oxidative stress injury. Current Neurovascular Research, vol. 13, no. 2, pp. 135-146. https://doi.org/10.2174/1567202613666160226152549.

SINGH, M., SINGH, K.P., SHUKLA, S. and DIKSHIT, M., 2015. Assessment of in-utero venlafaxine induced, ROS-mediated, apoptotic neurodegeneration in fetal neocortex and neurobehavioral sequelae in rat offspring. International Journal of Developmental Neuroscience, vol. 40, no. 1, pp. 60-69. http:// dx.doi.org/10.1016/j.ijdevneu.2014.10.007. PMid:25450524.

SINHA, B.K., 2020. Role of oxygen and nitrogen radicals in the mechanism of anticancer drug cytotoxicity. Journal of Cancer Science E Therapy, vol. 12, no. 1, pp. 10-18. PMid:32494339.

THASE, M., ASAMI, Y., WAJSBROT, D., DORRIES, K., BOUCHER, M. and PAPPADOPULOS, E., 2017. A meta-analysis of the efficacy of venlafaxine extended release $75-225 \mathrm{mg} /$ day for the treatment of major depressive disorder. Current Medical Research and 
Opinion, vol. 33, no. 2, pp. 317-326. http://dx.doi.org/10.1080/ 03007995.2016.1255185. PMid:27794623.

U.S. FOOD AND DRUG ADMINISTRATION - FDA, 2000 [viewed 27 March 2021]. Redbook 2000: IV.C.1.d. Mammalian Erythrocyte Micronucleus Test [online]. Available from: https://www.fda. gov/regulatory-information/search-fda-guidance-documents/ redbook-2000-ivc1d-mammalian-erythrocyte-micronucleus-test
U.S. FOOD AND DRUG ADMINISTRATION - FDA, 2006 [viewed 27 March 2018]. Effexor ${ }^{\circledR}$ (venlafaxine hydrochloride) [online]. Available from: https://www.accessdata.fda.gov/drugsatfda_ docs/label/2006/020151s044,020699s071lbl.pdf

WORLD HEALTH ORGANIZATION - WHO, 2017. Depression and other common mental disorders: global health estimates. Geneve: WHO, pp. 1-24. 